\title{
Some Recent and Future Developments in the Study of Social Representations
}

\author{
BERNARD GUERIN \\ University of Waikato and Visiting Researcher, Keio University
}

\begin{abstract}
Social representation theory studies social knowledge created by groups which becomes objectified, as if it existed outside of social processes. In this paper, some new themes and directions for social representation research are discussed. Overall, it is suggested that more emphasis be placed back onto the group dynamics which create, change and maintain social representations. Too much emphasis, perhaps, has been put on finding and describing the objectified knowledges rather than the social processes which sustain them. In particular, more needs to be known about the groups themselves which create and maintain social representations, and the conditions for such groups' existence. The methods for research need to reflect the social processes over time and anthropological methods of research might help in this regard. It is then argued both that social relations are a prerequisite for social representations and that social representations can be utilized by groups for various functions. Both these points emphasize that social representations exist through, and are maintained by, group dynamics, which need to be studied in addition to descriptions of the content of social representations.
\end{abstract}

Social representation researchers study how groups of people report, talk or represent various types of knowledge. For example, in Herzlich's (1971) study she looked at how people talked about their health and illness. There seemed to be consistent ways of talking about health and illness, but these were different for different groups of people. The main points about social representations are well documented and cannot be repeated here in detail (Farr \& Moscovici, 1984; Guerin, 1992; Sugiman,
1995). What I wish to do is to discuss some recent advances and critical extensions of social representation theory after a very brief introduction.

\section{Social representation theory}

Social representation theory has studied knowledge structures that are shared by groups of people. The major argument is that people construct knowledge for the function of allowing people to talk about events and things that

I wish to thank the Japan Foundation and Keio University for supporting this work, and Toshio Sugiman, Tomohide Atsumi, Katsuya Yamori, and Toshio Yamagishi for helpful comments and discussion about this material. An earlier version was presented at the 42nd Annual Conference of the Japanese Group Dynamics Association.

Correspondence concerning this article should be addressed to Bernard Guerin, Department of Psychology, University of Waikato, Private Bag, Hamilton, New Zealand. 
are unfamiliar to them. The original example came from Moscovici's (1961) pioneering study. In the 1950s, the French public were confronted by something new they did not understand-the psychoanalysis proposed by Freud.

Moscovici's question was not whether the public understood psychoanalysis correctly or not, but how they learned about psychoanalysis and whether different groups learned differently.

After a large amount of research using interviews and questionnaires, Moscovici proposed that there were three ways that social groups had confronted the unfamiliar knowledge of psychoanalysis. First, the Catholic Church had assimilated the new knowledge for church members by relating it to familiar ideas. For example, lying on a couch in psychoanalysis was similar to the Catholic confessional. Second, the Communist Party had denied any truth to psychoanalysis and suggested that members ignore it as a capitalist strategy for control. Last, the newspapers had popularized psychoanalysis by assimilating to very simplified concepts from everyday understanding and by making jokes about psychoanalysis.

The details of how psychoanalysis was confronted are unimportant; the important point here is that people learned about psychoanalysis (made it familiar) in different ways according to their group. Thus Moscovici proposed that the different groups constructed different social representations of psychoanalysis, and that this helped people anchor their beliefs about something unfamiliar to them.

Another important point from Moscovici was that the knowledge became objectified, as if it were independent of the people who produced it. People confronted their groups' social representations in most cases and did not personally invent them. So the knowledges appeared to be outside of them and even outside of their group.

The final point for this brief introduction is that Moscovici also proposed that people's beliefs, attitudes, and attributions were derived from the social representations of their group, rather than social representations being an amalgam of their pre-existing beliefs, attitudes, and attributions. This meant that the study of attitudes and attribution theory needed to be studied in the context of larger social representations in society and not as products of individual cognitions (de Rosa, 1993; Hewstone, Jaspars \& Lalljee, 1982).

\section{Extensions and developments}

Having given a very brief introduction to social representations I now wish to discuss what I believe are the major contemporary issues in social representation research and theory. The major point of the four themes I will make is that even though social representations become objectified as knowledge and appear independent of the people who produced them, they still depend upon the social groups for maintenance and so we still need to study the group dynamics involved as well as the content of the social representations.

\section{Theme 1: Defining social representation groups}

The first theme that appears in the social representation literature is that of how we should measure and define the groups involved in social representations. Traditional studies of social representations have used large populations, such as readers of the French popular Newspapers, the French Catholic Church, and the French Communist Party (Moscovici, 1961). But small groups can also develop and maintain social knowledge. We form strong identity groups, subcommunities and sub-cultures which affect much of our behavior. These are not exotic groups but common everyday groups.

At the same time, social representation groups cannot be defined as statistical or numerical groups. We need to specify and define special properties to be a group. Räty \& Snellman (1992) have suggested that, "Only structured groups are real groups, in which human relationships are organized by rights, duties and roles" (p.7). But this is poorly explained, be- 
cause the "rights, duties and roles" are only the verbal specifications of what keeps groups together. As will be discussed later in this paper, rights, duties and roles must have assumed precontractual social relations before they can be effective.

\section{Theme 2: The maintenance of socially con- structed knowledge}

As mentioned above, language and similar discursive forms appear to exist independently of the physical environment, as an objectified, "reified universe". Often the social representation content has no referent in the world as science knows it, for example, talking about Santa Claus or fairies. Such socially constructed knowledge needs more explanation, and many researchers now looking at the finer details of how this occurs (Gergen, 1985; Guerin, 1992).

My suggestion, only one of many, has been that a pre-requisite for the social construction of fictitious knowledge is a group with generalized exchange or loose social reinforcement (Guerin, 1994a; Sahlins, 1965; Yamagishi \& Cook, 1993; Yamagishi \& Yamagishi, in press). In generalized exchange groups, behavior and talking can occur which is not immediately punished if it does not correspond to the world as known perceptually. Social reactions and reciprocal exchanges occur over a longer time period, so arbitrary, counter-intuitive and fictitious behavior or talking become possible, because they are not immediately stopped by other people who might disagree or think they are strange. In groups for which any reciprocal exchange depends very tightly upon what is done and said, talking and behaving with respect to fictitious knowledge would be less likely. Any arbitrary, counter-intuitive or fictitious behavior or talking would be laughed at or punished.

So one suggestion is that generalized trust, generalized exchange relations, or a loose system of social reinforcement is a prerequisite condition for social representation. This equates the groups which form social repre- sentations with the "collectives" of Durkheim (1912), the "verbal communities" of Skinner (1957, Guerin, 1994a), the "linguistic or speech communities" of Saussure (1983/1916), the "generalized others" of Mead (1934), and groups with generalized exchange or generalized trust (Sahlins, 1965; Yamagishi \& Cook, 1993; Yamagishi \& Yamagishi, in press).

\section{Theme 3: Methods for studying social repre- sentations}

In the social representations literature at the moment, there are also many general questions being asked about the methods that are used in this research. Should interviews, selfreports, or content analysis be used? Should rating scales such as Likert items be used in social representation research? Should statistical approaches be used, or is statistics incompatible with phenomena like social representations?

The first problem, perhaps, is that most social representation researchers have been trained in social psychology, and have brought to the study of social representations the research and analysis methods of social psychology. So for historical reasons, I believe, the methods used in social representation research are typically those of social psychology. Even new methods, such as discourse analysis, have come into this area through social psychologists rather than linguists (Galli \& Nigro, 1987; Gergen, 1988; Gergen \& Gergen, 1988; Potter \& Litton, 1985).

As will become clear below, when the subject area of social representations begins to include more emphasis on group dynamics, I believe that the methods of anthropology and sociology will become more important in the study of social representations. Studying particular groups over a longer time frame is the approach traditionally utilized in anthropology and anthropologists have, I believe, many useful methods which could be employed in social representation research (Epstein, 1969; Geertz, 1973; Harrison, 1992: Mitchell, 1969). These methods have their own problems but as additional 


\section{Bernard Guerin}

methods they would be useful.

A second question about methods is that social representation researchers typically use analytical methods which are designed to find representations that are coherent or consistent within groups of people. Typically, measures are made through interviews or rating scales which are put into factor analysis packages or cluster analysis packages. These search (statistically) for groups of similar ratings or answers. So Group A might show common attitudes, beliefs, and attributions, which are consistent and coherent within Group A, while Group B shows another typical pattern which is consistent and coherent within Group B but not with those of Group A (e.g., Echabe \& Rovira, 1989; Hewstone, Jaspars \& Lalljee, 1982).

This is important work, and I am not suggesting that it should stop. But Doise and others have questioned whether the methods used actually find more coherence of representations than there is in reality (de Rosa, 1993; Doise, Clémence \& Lorenzi-Cilodi, 1993; Paéz \& Gonzaléz, 1993; Sotirakopoulou \& Breakwell, 1992). As suggested below, and by others (Moscovici, 1984), social representations are being negotiated all the time, and constantly change in small and large ways. Further, Potter and Litton (1985) found that the people in both groups they studied knew the social representations of the others but did not agree with it. So a simple version that each group has its own social knowledge and no other social knowledge is not correct. Finding simple clusters of beliefs in different groups is perhaps an unrealistic expectation and methods which search for such a condition should be used and interpreted with caution.

\section{Theme 4: Social representations and group dynamics}

A final theme in the representation literature shows that group dynamics is being put back into the study of social representations, as it was in the beginning (Festinger, 1954; Moscovici, 1961). This has begun from many angles and I believe will prove to be an important direction for the future.

One of the main properties of social representations is that they become objectified, in the sense that they appear as external events, and as independent of the people who produced them in the first place. I believe it is for this reason that social representations have usually been studied without studying the social processes or group dynamics behind them. In a similar way, discourse analysis and dialogical accounts treat words and representations as existing independently of the social groups that produced them in the first place (e.g., Gergen, 1988; Gergen \& Gergen, 1988; Potter \& Wetherall, 1987; Sampson, 1993).

Such attempts to study social knowledge without looking at the group dynamics has been criticized by, amongst others, Räty \& Snellman (1992), Sá (1994), Echebarria and Gonzales (1993), and Guerin (1994b). It is argued that although the social representations look separate from the social processes, they are created and maintained by social processes which must also be studied to understand fully what is happening. Sá has suggested affinities with the work of Pierre Bourdieu (1977, 1991), and both Sá and Guerin have suggested affinities with modern behavior analysis (Sá, 1994; Guerin, 1992, 1994b).

This theme relates closely to the theme discussed above about methods. There should be renewed attempts to look at the process as well as content of social representations. I like to call this social negotiation. How are social representations formed and how do they change? How are they used in communities, what are their functions? This was Moscovici's original approach, and anthropologists have methods to research these topics which social psychologists could usefully adopt.

To make these points clearer I wish to discuss two areas of interest which require that we look at social process, not just the content of social representations.

First, one of Durkheim's major points was 
that in any contractual social relation or rule-governed relation, there must be a precontractual contract (Durkheim, 1912). A contract will not maintain unless the parties involved have already settled the power relations between them; otherwise there is nothing to stop one party simply breaking off the agreement. The group dynamics or relative social contingency outcomes need to be settled in advance.

In the same way, if people in a group tend to agree with each other about a social representation then there must be power relations or group dynamics which came before the representation did. With no pressure beforehand to agree with a community's social representation people would not necessarily agree with it nor continue to agree with it. This is abundantly clear with socially constructed fictitious knowledge, for example.

Let consider an extreme example. If we found a group which showed complete consensus about a social representation, such that all members agreed completely about the content, this would indicate to me that there were very tight social power relations in that group. Such a situation might only occur in a cult group, or other forms of extreme autocratic rule.

What this illustrates is that whether or not a social representation is coherent and consistent between members depends upon the social relations between the members of that group, not just something about the social representation itself. Any consistent social representations in a group reflect the group dynamics of that and are not a property of the content of the representations. Describing social representations is important but we also need to discover the social processes behind the social constructions.

As another illustration, evidence shows that people in groups can report several points of view but "believe" the one that most members of their group believe. Potter and Litton (1985), for example, studied social representations about why a riot had occurred in England. Like traditional social representation studies, they found that two different groups tended to agree with two different representations. But the interesting point for our purposes is that both groups. knew the representation of the other. That is, both groups could report both representations, but depending upon the group dynamics they would believe only one to be true.

Elsewhere, I have suggested the same points for attitudes and beliefs; that their consistency and coherence depends upon the group processes rather than on anything about the attitudes or beliefs themselves (Guerin, 1994c). Attitude-behavior and attitude-belief consistency, it was argued, depend upon the social relations (Guerin, 1994c) rather than upon something about the attitude and belief content (e.g., Ajzen \& Fishbein, 1980). So the content, coherence, consistency and form of the social representations all depend upon the social power relationships in the group, which means that the group dynamics must be an integral part of studying social representations.

The second area of interest which can help clarify why social processes need to be studied along with social representations, follows from a remark made above: that social representations can be used by group members.

The common function of social representations, according to Moscovici (1984), is that they make familiar to us events and things which are actually unfamiliar or unknown. Few people in France in the 1950s knew what psychoanalysis was, so people looked to their groups to make the topic familiar (Moscovici, 1961; also Guerin, in press). As another example, few people in 1994 know what the idea of Cyberia is all about, so we would predict that most people will learn from their groups how to react when hearing about Cyberia for the first time, what attitudes to hold, what attributions to make, etc. [Cyberia is the name given by a loose group of people (e.g., Rushoff, 1994) who envisage a future united world system based around worldwide computer communication through Internet, drug, taking, virtual reality computer-ware, and 


\section{Bernard Guerin}

the demise of international corporate monopolies.]

But there is another function of social representations I believe. As a process, social representations can be used to influence members of a group. Once there are social representations established for a group, they can be used when negotiating social life. For example, when a Church wishes to increase compliance, it can ask members to state their beliefs aloud: Do you believe in the one true church? Do you believe in the one true God? Or, when leaders wish to gain more power within a group, they can change the social knowledge slightly to favor themselves (Geertz, 1873, p. 146). To suggest this point even more strongly, it might be the case that social representations are primarily verbalized in order to influence members. Otherwise, why talk about them? Many people will first use the idea of Cyberia to impress other members of their groups.

There is perhaps another function of social representations, however, which also goes back to Durkheim (1912; also Rappaport, 1984). Reciting and discussing social representations in social groups can function as a ritual event, to increase stability of group (Guerin, 1994a). A good way to maintain or stabilize a group is to sit around and repeat commonly held beliefs and attitudes, or make jokes about other people who hold different beliefs and attitudes. This helps to create group solidarity (Rappaport, 1984, p. 347).

It should be noted that in both these cases of other functional uses of social representations, the content of the representation was not particularly important. What was important were the group dynamics which utilized the social representations. This also suggests, then, that we should not study social representations separately from the social processes which create and maintain them, even if the representations look as if they are separate, independent, and objectified. Social knowledges might look like products of an independent "group mind", but they cannot be studied separately from the people that create and maintain them.

\section{Conclusion}

Given that social knowledge can be thought of as objectified knowledge and also as social process, the questions are sometimes asked: "Which came first?" and "Which is correct?" If one thinks in temporal terms about social knowledge, then I believe that both are correct. In a similar way, Saussure realized that language needs to be studied both as an independent object, la langue, and as a social process, parole (Saussure, 1983/1916). I have emphasized the latter here because I believe it needs readdressing in social representations research.

Originally, there must have been people before social knowledge was ever verbalized or constructed, especially fictitious knowledge. In our lifetimes, however, Moscovici is correct that we confront social knowledge as if it came from outside of social processes. Most of our knowledge was there before we were born, we did not invent it ourselves. Some rules and beliefs can hurt us or even kill us, so once again it appears to be outside of social processes. On the other hand, we can change social knowledge sometimes through group dynamics, and subcommunities regularly invent or discover new social knowledges. But they only change social knowledge by changing people, so both must go together.

The future of studying social representations and all social knowledge lies, I believe, in unravelling how what we say is created by us but then used towards us as if it was an independently functioning "thing". The requires studying both social representations as having an independent content, and as a social process which creates and shapes that content through group dynamics and then uses the representations to maintain or change the social influence processes.

\section{References}

Ajzen, I., \& Fishbein, M. (1980). Understand- 
ing attitudes and predicting social behavior. Englewood Cliffs, NJ: Prentice-Hall.

Bourdieu, P. (1977). Outline of a theory of practice. London: Cambridge University Press.

Bourdieu, P.(1991). Language and symbolic power. Cambridge, England: Polity Press.

de Rosa, A. S. (1993). Social representations and attitudes: Problems of coherence between the theoretical definition and procedure of research. Papers on Social Representations, 2, 178-192.

Doise, W., Clémence, A., \& Lorenzi-Cioldi, F. (1993). The quantitative analysis of social representations. New York: Harvester Wheatsheaf.

Durkheim, E. (1912). The elementary forms of religious life: A study in religious sociology. New York: Macmillan.

Echabe, A. E., \& Rovira, D. P. (1989). Social representations and memory: The case of AIDS. European Journal of Social Psychology, 19, 543-551.

Echebarria, A., \& Gonzales, J, L. (1993). Social knowledge, identities and social practices. Papers on Social Representations, 2, 117-125.

Epstein, A. L. (1969). Gossip, norms and social network. In J. C. Mitchell (Ed.), Social networks in urban situations: Analysis of personal relationships in Central African towns. Manchester: Manchester University Press.

Farr, R. M., \& Moscovici, S. (Eds.). (1984). Social representations. Cambridge: Cambridge University Press.

Festinger, L. (1954). A theory of social comparison processes. Human Relations, 7, 117-140.

Galli, I., \& Nigro, G. (1987). The social representation of radioactivity among Italian children. Social Science Information, 25, 535-549.

Geertz, C. (1973). The interpretation of cultures. New York: Basic Books.
Gergen, K. J. (1985). The social constructionist movement in modern psychology. American Psychologist, 40, 266-275.

Gergen, K. J. (1988). If persons are texts. In S. B. Messer, L. A. Sass, \& R. L. Woodfolk (Eds,). Hermeneutics and psychological theory (pp. 28-51). New Brunswick, NJ: Rutgers University Press.

Gergen, K. J., \& Gergen, M. M. (1988). Narrative and the self as relationship. In $\mathrm{L}$. Berkowitz (Ed.), Advances in experimental social psychology (Vol. 21, pp. 17-56). San Diego, CA: Academic Press.

Guerin, B. (1992). Behavior analysis and the social construction of knowledge. American Psychologist, 47, 1423-1432.

Guerin, B. (1994a). Analyzing social behavior: Behavior analysis and the social sciences. Reno: Context Press.

Guerin, B. (1994b). Using social representations to negotiate the social practices of life. Papers on Social Representations, 3, 177-183.

Guerin, B. (1994c). Attitudes and beliefs as verbal behavior. The Behavior Analyst, 17, 155-163.

Guerin, B. (in press). The utilization of group views when giving opinions about unknown, group-salient or neutral items. Journal of Social Psychology.

Harrison, S. (1992). Ritual as intellectual property. $\operatorname{Man}(N . S), 27,.225-244$.

Herzeich, C. (1973). Health and illness: $A$ social psychological analysis. New York: Academic Press.

Hewstone, M., Jaspars, J. M. F., \& Lalljee, M. (1982). Social representations, social attribution and social identity: The intergroup images of 'public' and comprehensive' schoolboys. European Journal of Social Psychology, 12, 241-269.

Mead, G. H. (1934). Mind, self, and society from the standpoint of a social behaviorist. Chicago: University of Chicago Press.

Michell, J. C. (Ed.). (1969). Social networks in 


\section{Bernard Guerin}

urban situations: Analyses of personal relationships in Central African towns. Manchester: Manchester University Press.

Moscovici, S. (1961). La psychanalyse: Son image, son public [Psycholoanalysis: Its image and its public]. Paris: Presses Universitaires de France.

Moscovici, S. (1984). The phenomenon of social representations. In R. M. Farr \& S. Moscovici (Eds.), Social representations (pp.3-69). Cambridge: Cambridge University Press.

Páez, D., \& Gonzaléz, J. L. (1993). A Southerner's response to an insular critique: Where to find the social and how to understand the use of clusters in our studies on social representations. Papers on Social Representations, 2, 11-25.

Potter, J., \& Litton, J. (1985). Some problems underlying the theory of social representations. British Journal of Social Psychology, 24, 81-90.

Potter, J., \& Wetherall, M. (1987). Discourse and social psychology: Beyond attitude and behavior, London: Sage.

Rappaport, R. A. (1984). Pigs for the ancestors. London: Yale University Press.

Räty, H., \& Snellman, L. (1992). Making the unfamiliar familiar: Some notes on the criticism of the theory of social representations. Ongoing Productions on Social Representations, 1, 3-13.

Rushkoff, D. (1994). Cyberia: Life in the trenches of hyperspace. London: Flamingo.

Sá, C de. (1994). Sur les relations entre représentations sociales, practiques socioculturelles et comportment. Papers on Social Representations, 3, 40-46.

Sahlins, M. D. (1965). On the sociology of primitive exchange. In M. Banton (Ed). The relevance of models for social anthropology (pp. 139-236). London: Tavistock.

Sampson, E. E. (1993). Celebrating the other: A dialogic account of human nature. Boulder, CO: Westview Press.

Saussure, F. de. (1983/1916). Course in general linguistics, London: Duckworth.

Sotirekopoulou, K. P., \& Breakwell, G. M. (1992). The use of different methodological approaches in the study of social representations. Ongoing Productions on Social Representations, 1, 29-38.

Sugiman, T. (1995). Group dynamics and regional development planning [In Japanese]. Journal of Infrastructure Planning and Management (Japan Society of Civil Engineering), No. 506/IV-26, 13-23.

Yamagishi, T., \& Cook, K. S. (1993). Generalized exchange and social dilemmas. Social Psychology Quarterly, 56, 235-248.

Yamagishi, T., \& Yamagishi, M. (in press). Trust and commitment in the United States and Japan. Motivation and Emotion.

(Received Nov. 14, 1994; Accepted Jan. 11, 1995) 